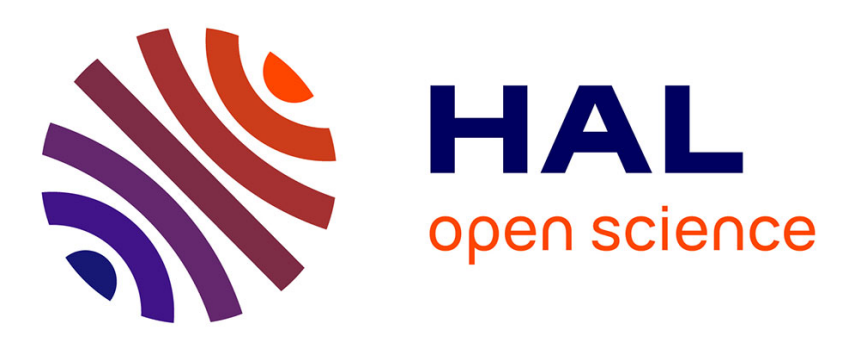

\title{
The limitations of whiteness and the boundaries of Englishness
}

Mary J. Hickman, Sarah Morgan, Bronwen Walter, Joseph Bradley

\section{To cite this version:}

Mary J. Hickman, Sarah Morgan, Bronwen Walter, Joseph Bradley. The limitations of whiteness and the boundaries of Englishness. Ethnicities, 2005, 5 (2), pp.160-182. 10.1177/1468796805052113 . hal-00571840

\section{HAL Id: hal-00571840 \\ https://hal.science/hal-00571840}

Submitted on 1 Mar 2011

HAL is a multi-disciplinary open access archive for the deposit and dissemination of scientific research documents, whether they are published or not. The documents may come from teaching and research institutions in France or abroad, or from public or private research centers.
L'archive ouverte pluridisciplinaire HAL, est destinée au dépôt et à la diffusion de documents scientifiques de niveau recherche, publiés ou non, émanant des établissements d'enseignement et de recherche français ou étrangers, des laboratoires publics ou privés. 


\section{thnicities}

Copyright $\odot 2005$ SAGE Publications (London, Thousand Oaks, CA and New Delhi) 1468-7968

Vol 5(2): 160-182;052113

DOI:10.1177/1468796805052113

www.sagepublications.com

\section{The limitations of whiteness and the boundaries of Englishness}

Second-generation Irish identifications and positionings in multiethnic Britain

MARY J. HICKMAN

London Metropolitan University, UK

SARAH MORGAN

BRONWEN WALTER

Anglia Polytechnic University, UK

JOSEPH BRADLEY

University of Stirling, UK

ABSTRACT The focus of this article is the second-generation Irish in England. It is based on data collected as part of the Irish 2 project, which examined processes of identity formation amongst the second-generation Irish population in England and Scotland. The article examines and maps identifications and positionings of second-generation Irish people and discusses how two hegemonic domains - Ireland and England - intersect in the lives of the children of Irish-born parents, with material and psychological consequences. Their positionings in multiethnic Britain are compared with those of 'visible' minority ethnic groups, and their narratives of belonging and non-belonging are analysed in terms of the limitations of whiteness and the boundaries of Englishness.

KEYWORDS Irishness $\bullet$ minority ethnic group 


\section{INTRODUCTION}

The research presented here is based on data collected as part of the Irish 2 project $^{1}$ which examined processes of identity formation amongst the second-generation Irish population in England and Scotland. It contributes to debates about ethnicity signalled in a Symposium on Ethnicity in this journal. In that issue of Ethnicities (1(1)) Nira Yuval-Davis called for specification of the heterogeneity of positionings and voices amongst second generations and asked what gender, class and other differences were inscribed in these positionings (Yuval-Davis, 2001). Rogers Brubaker argued, in that same issue, that when considering racial, ethnic or national groups it was not sufficient to refer to them as socially constructed entities; what was required was a linking of macro-level outcomes with micro-level processes. In other words, we need to be able to specify how and when people identify themselves, perceive others, experience the world, interpret their predicaments and orient their actions in racial, ethnic or national terms (Brubaker, 2001). This research conceived in the late 1990s speaks directly to these concerns. It focuses on a group of people often perceived to have assimilated within multiethnic Britain but who have recently been recognized in the public domain as a distinct constituency.

In the case of the second-generation Irish, their white skin, local accents and assumed cultural similarities have been taken to reflect the reality of a population easily assimilated to the 'white' English majority (see Modood, 1996; Goulborne, 1998). Consequently most reference to the Irish in England is to the Irish-born population, the migrant generation, assumed to be distinguishable by their accent and place of origin. Assumptions about the homogeneity of the white population also underpin this positioning of the second-generation Irish in Britain. The installation of the notion of white homogeneity was a key element of official discourses in the reconfiguration of the ethnoracial regime in Britain in the 1950s and 1960s (Hickman, 1998a, forthcoming). It was a view which assumed that all people who were white smoothly assimilated into the 'British way of life' and that the 'problems' resided with those who migrated and possessed a different skin colour. The myth of homogeneity required the denial of differences amongst the white population as it racialized the boundaries of the nation and masked the hierarchy of belonging that constitutes Britishness. This myth has been under pressure for at least the past 20 years. The inauguration of the ethnic/cultural origin question in the 1991 British Census, and devolution to Scotland, Wales and Northern Ireland in the late 1990s, signalled processes long underway to challenge the hierarchy of belongingness within Britishness. As a result, Englishness is now more commonly asserted as a specific ethnicity. However, its conflation with Britishness is still often apparent. 
A reductive model of race and ethnicity has marked British sociology and cultural studies since the 1960s. Even 'New Ethnicities' theory, which entailed a move beyond a notion of hybridity, solely characterizing the inner life of the postcolonial subject, to a complex understanding of multiple positionings, did not with any consistency speak beyond a diochotomizing black/white paradigm (see Hickman, 1995; Cohen, 1999; Campbell, 2002). The deconstruction of the white universalizing centre is as necessary as analysing the multiplicities and hybridities of Britain's perceived postcolonial subjects, if the hierarchical character of this black/white binary is to be fully challenged (Young, 1990). Addressing whiteness in the British context is often, however, not so much a process of deconstructing a racialized category but, rather, an extension of class analysis (see, for example, Bonnett, 2000 who, like many others, is unable to deal sufficiently with the submerged ethnicities within 'whiteness' when examining Britain).

Some of these assumptions of white ethnic homogeneity are already under critical review. A number of writers on race and ethnicity have noted the distinctiveness of the Irish population and either suggested or commented on the need for an analytical framework in which to place Irish experiences in multiethnic Britain (see Cohen, 1988; Anthias and YuvalDavies, 1992; Brah, 1996; Lewis, 1998). The Commission for Racial Equality published a report on discrimination and the Irish community in Britain (Hickman and Walter, 1997), which established that Irish immigrants were subject to racialization, social disadvantage and discrimination. Three years later, the Runnymede Trust published The Report on the Future of Multi-ethnic Britain (Parekh, 2000). This was a landmark report on a number of counts, one of which was that its analysis of minority ethnic groups bridged the black/white binary for understanding racial and ethnic exclusion in Britain (see also Modood et al., 2002); it featured data and commentary on the Irish and Jewish populations in particular. The introduction of an Irish category to the ethnic origin question in the 2001 British Census was another landmark, albeit a problematic one, in marking the distinctiveness of the Irish component of the British population and diversity within whiteness. (The form of the question was not as recommended to the Office of National Statistics by those who sought the inclusion of an Irish category, see Walter, 1998.) To some extent the recognition of the problematic experiences and positionings of many of the Irish-born has led to a reconsideration of the second generation. Data on the health of the Irish in Britain noted the crossgenerational impact of health penalties such that the second generation experience levels of poor health and excess rates of mortality compared with the British population that cannot be explained by class or age (for example, see Harding and Balarajan, 1996).

Two surveys of second-generation teenagers in the 1980s highlighted the importance of Irish identifications for this group. In Philip Ullah's studies 
$(1985,1990)$ over 75 percent of his sample of second-generation teenagers in Birmingham self-identified as either 'half-English, half-Irish' or as 'mainly Irish'. He concluded that the second-generation Irish thought they belonged to a group who were viewed as of low status.

I found that anti-Irish prejudice was widely experienced, and that questions relating to identity formed a major issue in the lives of many of these people. It was clearly not the case that they had been assimilated to a greater extent than other minorities, or that they had escaped the many problems associated with second-generation youth. (Ullah, 1985: 310)

Ullah argued that because they are (predominantly) white, secondgeneration Irish could use the strategy of psychologically leaving their group as a means of avoiding unpleasantness, distancing themselves from those things likely to emphasize their Irishness. In Mary Hickman's survey $(1990,1998 b, 1999)$ of the identities of second-generation pupils in Catholic schools in London, 81 percent named either 'Irish' or 'of Irish descent' as their primary identity. They all had two Irish-born parents, most regularly visited Ireland and were likely to be involved in Irish social and cultural practices. Hickman argued that whereas education has been a prime way in which the public mask of Catholicism has rendered Irishness invisible in Britain, the family has provided a counterpoint to the school and its incorporating strategies (Hickman, 1995).

More recent research has been concerned with the agency of the second generation, focusing on how they are constructively engaged in securing their identities and not just as the recipients of structural processes. These texts describe a population who utilize both multiple and syncretic identities to negotiate their lives (apart from those cited below, see also Free, 1998; Arrowsmith, 2000). Sean Campbell's research (1998, 1999, 2000) about second-generation Irish musical 'routes' which have offered a critique of Englishness - in studies of groups such as Oasis and The Smyths - is a case in point. He argues that the Gallagher brothers (the founders of the group, Oasis), for example, are part of a diasporic, hybrid musical form in which is dramatized the ambivalence that second-generation Irish people in England experience towards Englishness. Another study focuses on how the second-generation Irish define and perform new versions of Irishness and argues that the complex racialized histories and geographies of the second generation provide a lens - from below - through which to deconstruct the black/white dualism in much Anglo-American academic work (Mac an Ghaill and Haywood, 2003). The autobiographical writings of second-generation Irish in England reveal that 'the desire for authentication is that which the second-generation imagination cannot not want' concludes Liam Harte (2003: 301), and he characterizes this quest as a search for an authentically hybrid identity, in which the coordinates of 'here' and 'there' might be creatively 'pestled together'. 
The study discussed here is about the identifications and positionings of the second-generation Irish at the two related levels of subjectivity/ 'ontology' and collectivity/'social category'. That is, it is concerned to address the meanings and constructions of ethnicity by individuals of Irish descent in England and Scotland and to examine the ramifications of the presence or absence of Irish ethnicities in political and public policy discourses and practices. First, it aims to critique the assumptions of white homogeneity which predominated in the literature on ethnicities in Britain up until the late 1990s, by excavating the forms of Irish identification submerged by the hegemonic category 'white' in Britain. Second, it aims to develop a framework for analysing the responses (or lack of responses) to the Irish option in the ethnic question of the 2001 British Census, by exploring the interpretations or narratives embedded in the responses of secondgeneration Irish participants in the research. And, third, in the context of devolution, it attempts to contextualize the specificity of (different) potential identifications and positionings of the Irish descent population in England and Scotland, in part reflected in the different Census categories used in each country. Bringing the Irish more systematically in to this British picture enables a fuller plotting and contextualization of the fluid patterns of multiethnic interactions and intersections. At the same time, this affords the opportunity of exploring the power dynamics of the hierarchical structures of belonging in contemporary Britain. This article is an early posting of this analysis and focuses on the Irish in England; it aims to examine and map out identifications and positionings of the second generation as revealed in discussion groups conducted in four English cities. A comparable analysis in Scotland is to follow.

Discussion groups were chosen as an exploratory tool in the first instance (they were followed by individual interviews) because a process of construction may take place within a group of people whose identities are invisible in the majority society, and who have no formal opportunities to reflect on their situation and this may be enabled and traced through group discussions. People with one or two Irish-born parents were invited to take part. We advertised extensively for discussion group members who were then chosen to provide an even gender balance overall and a class and age mix reflecting what we knew of the demographic and socioeconomic profile of the second-generation Irish population cohort (see Hickman et al., 2001). Our qualitative analysis of the transcripts of their conversations is not intended to be representative of all second-generation Irish people in Britain, but to explore ways in which the identities and positionings of second-generation Irish people are expressed and experienced in everyday life. The data collected from the discussion groups allow us both to draw out major themes, which will be shared to a greater or lesser extent with other people of Irish parentage, and to point to contextual variations at a number of spatial scales. The four centres selected in England were: 
London, by far the largest single destination for Irish migrants in the 20th-century; Manchester with a multigenerational Irish community with roots back to the early 19th-century; Coventry where a substantial Irish population dates almost entirely from the massive out migration of the 1950s; and the market town of Banbury in Oxfordshire, selected for its small Irish population, also of post-Second World War origin. The discussion groups all took place in the months leading up to, or immediately after, the 2001 British Census.

\section{IDENTIFICATIONS AND POSITIONINGS OF THE SECOND-GENERATION IRISH}

At the beginning of each of the discussions, participants were asked how they would identify themselves (they were also shown a copy of the 2001 ethnic question). A participant in one of the Banbury discussion groups was unclear about how he wanted to respond but very clear as to the dilemmas the question encapsulated for him. We give the complete quote of his response (all names have been changed) because early in the research he signalled issues which were to arise many times in all locations.

James: It is a question that has arisen, because I have been cornered almost, are you English or Irish? It reminds me that there was a bit in It Ain't 'Alf Hot Mum, the porter is asked by one of the soldiers, 'are you in favour of Indian independence or not?', and he said 'well it depends who I am talking to at the time'. It feels a little bit like that sometimes. It's like an England-Ireland football match, who do you support. I normally support Ireland, is that just an Englishman wanting to support the underdog, it is difficult isn't it? I am not Irish. If I went over to Ireland and said to them over there, I am Irish, they would laugh at you, they would think it was really funny. As far as they are concerned you are English, but you are not English, not English in the same way as people born and brought up here, and have English parents. You have a different element to you, which gives you a slightly different outlook on life, I think anyway.

The form of the Census question with its sub-categories of 'British', 'Irish' or 'Other' under the conglomerate category of 'White' echoed the challenge faced by many second-generation Irish people when giving voice to 'difference' in their daily lives. Several themes here were regularly alluded to by other participants. These were: the challenge from 'English' people when a second-generation Irish person differentiated themselves from 'the English/British'; comparison with the situation of other minority ethnic groups; reference to the strategy of varying self-presentation according to context or to the people being addressed; reference to sporting 
allegiances as a way of gauging 'who you really support' (and therefore 'are'); reference to the derision with which claims of 'being Irish', by people with English accents, can be greeted in Ireland; and the insistence of not being 'English'/'British' primarily because of differences in upbringing.

A variety of identifications were voiced by the participants and broadly these are represented by five different positionings: 'being English'; 'not being English/British'; 'being Irish'; 'being half-Irish and half-English/ British'; and 'being local'. These are identifications that individuals can hold at any one time, but it is also clear that individuals can move in and out of them over time or juggle simultaneously a number of different positionings. Each positioning is in turn a hybridized identification. We are not arguing that these positionings represent a continuum along which it is possible to chart the degree of assimilation of an individual or group, rather at any one time or in a particular context or at a particular point in the life cycle, one of these points of identification may represent the narrative that an individual may utilize in response to the question 'are you Irish or English' or in response to their difference being denied or rendered problematic.

\section{On 'being English' and on 'not being English/British'}

We begin with a consideration of the ways in which people who represented themselves as 'being English' (a small number, all in Banbury) were positioned in comparison with people who primarily addressed their identity in terms of the impossibility of 'being English' or 'being British'. Those who said they were 'English' were initially clear in choosing their identity but, ultimately, in conversation these seemingly straightforward declarations were qualified in various ways. For example, 'if I am with Irish people I will mention it [I am Irish]'; or 'I always stipulate I am English. . . . where there is an Irish presence, then I would raise the point, and talk about how I am half Irish'. Some of those who said they 'felt' English contextualized their selection, by referring to negative experiences as children when they became aware that as members of a second generation: 'You are not as Irish as everybody else who is Irish;' or: 'When we were younger we termed ourselves as plastic Paddies, half there but not quite.' These caveats reveal carefully calibrated decisions about when to declare an Irish background. They also demonstrate concerns about the authenticity of claiming to be Irish when this is not accepted by 'everybody else who is Irish' and clearly locate the second-generation differently to the Irish-born.

One man in Banbury describes why he would select English or British as his identification:

Kieran: ... on the boxes [in the Census] I would put down that I was either English or British, because the Irish thing has never been an issue as far as I was concerned. . . . Funnily enough, I would probably say, I've considered myself more Irish than I did before. When I was growing 
up, it was never an issue, apart from at school. I was educated by Christian Brothers, but there were other members of staff there, mainly the Welsh, who would pick on people with Irish names and things like that. I felt that was a bit unfair at the time, simply because I had an Irish name that I should be picked on.... I think the other crucial bit was that my dad fought in the war, so it was never that issue. I know a lot of the Irish went home at the time of the Second World War, but he felt there was nothing in Ireland for him, that they'd supported him in part during the 1930s, so he owed it to them. I think that had an impact as well, that he actually fought on the side of the British in the war.

Kieran reveals that the motive 'to be English' can stem from a desire to distance oneself from anti-Irish jibes as a child and also involves a distancing from an Ireland, which had 'rejected' his father, compared with the opportunities England had afforded his parents. He refers to his father's participation in the Second World War, which is a touchstone of English identity. His self-definition as English therefore is defined against 'being Irish', which he is rejecting as his father has done.

In contrast, one man in Coventry who identified himself as a "Coventry kid' and as Irish, of which he commented 'the only true "Coventry kid" is the man with a shamrock in his turban', had the following to say about not being English:

Patrick: I find I can't throw any allegiance behind England whatsoever, although I do feel I am a member of the wider community, including the Scots, English, Welsh, Irish and Asians. In terms of my Englishness I have put not at all, because I think that it would be nice to be English, but for me in its current form English is, and I'm sorry for saying it, a little bit unattractive. Because, I think the most important thing, although we don't often admit it, or look at it hard enough, or ask hard questions about what it means to be English. But, an essential component part of being English is being white. The lad up Friars Hill road stays an Asian, regardless of wherever he is born. If he is born in Coventry and wears a turban he is a 'Paki' or an Asian, he carries a certain Asian identity regardless of his birthplace. Afro Caribbean people remain West Indians, Jamaicans regardless of their birthplace. English for me seems caught up with being white at the moment, Cliff Richard was born and raised in India, and has no problem at all selling himself as an Englishman does he? Although it might be nice to be English in the future, I say until they want the Asian, I don't want the English.

In Coventry and London the awareness of the participants that they were part of multiethnic cities contextualized the discussions of their identities. Patrick takes as a given that second-generation Irish people are situated in a context in which only certain groups, 'whites', are acceptable as English and therefore, in his view, birthplace is an irrelevant criterion for being 
English. He is suggesting that in identifying as a 'Coventry kid' and as Irish he is both being true to himself and exercising a choice because he would not want to be English as it is presently constituted. This could be interpreted as the exercise of the privilege of being 'white' but the rejection of Englishness.

Later in the same discussion a woman described how a tutor on her nurses' training course identified her Irishness by her name and 'he was absolutely disgusted'. In response to her, Patrick gave an account of how, when he got an apprenticeship in the local car factory, he was identified as an Irish Catholic. He was immediately subject to remarks such as 'how many nail bombs have you made', his response was 'I didn't know which way to turn, what to say, I was 16 just, and I thought to myself is this how people really think of us'. So his apparent mature exercise of choice about being English or not takes on a different resonance as does his earlier description of how when he was 17-18 years old 'I tried to be English, I thought I am from England I must be English, it must be my nationality. I tried it a lot for a while, and it didn't fit properly, it felt like acting, 'rule Britannia', and I couldn't get any inner feeling about it at all'.

Patrick is effectively mobilizing both a local identity and the Irish identity available to him amongst a number arrayed against 'being English' in order to exclude himself from an Englishness which is characterized by a set of practices around whiteness with which he does not want to be associated. He recognizes that Englishness as an ethnic identity is mobilized to exclude Asians so he is mobilizing Irishness to distance himself, because he is white, from this racialized 'discourse of Englishness'. He is simultaneously grounding both himself and the Asian 'lad up Friars Hill' into a local context. His act of solidarity can be fully understood in the context of his own experience of racialized verbal attacks for being an Irish Catholic when he was a young worker and in the light of his unsuccessful attempts 'to be English'. Juxtaposing the accounts of both Kieran and Patrick of their early experiences of anti-Irishness reveals how their different responses can be understood in terms of family background, local context, and political frameworks.

\section{On 'being Irish'}

Participants in the discussion groups characterized 'being Irish' (always articulated in the sense of 'being Irish' for the second generation) in two main ways, both of which related to their early developing awareness of 'difference'. As children, either they observed responses of people they took to be English to their parents, which marked the family's difference, or they became aware of differences in cultural practices, by visiting or staying in friends' homes or by observing others in the neighbourhood. These cultural practices became what they associated as distinctively 'Irish' 
and what they often celebrated. For some people both these processes occurred, sometimes intertwined. A discussion in one of the Manchester groups illustrates this. One man spoke of his own feelings about being Irish and the impact of something his brother observed.

Liam: I was very aware of it [being Irish], but I always felt intensely positive about it, and very defensive about it and my mum and dad. My brother had a story of when he was a little boy on the bus, the bus conductor said 'move along there, Paddy' in an unpleasant manner. My dad just looked at him, but it was a pivotal event in my brother's mind, he wanted to scamper up and kill this bus conductor, so I was really aware of being different.

The witnessing of incidents in which their parents experienced negative responses once identified as Irish (accent usually being the trigger) could have a searing impact. Audibility is the prime marker of Irishness in England, confirming the assimilationist assumption about the second generation (see Walter, 2000). However, as this extract demonstrates, children can 'experience' the hostilities that may be generated in their parents' everyday encounters.

In a later part of the discussion of the same group, the following observations were made about cultural practices. Here the participants discuss the social contexts in which they became aware of 'difference'. These individuals have grown up in areas where they met or went to school with people they identified as 'English'. Difference for them as children was marked by accent, artefacts, habits, atmosphere, opinions, food, hospitality and sociability. Awareness of how different they and their families were came about through their own observations, emotional responses and as a result of the comments of others.

Liam: I became really aware of how different I was from some middle-class English people, I was only about 6 . My best friend at school, I went to his house, he lived in Stretford, he wasn't a poncy middle-class at all, but he was English. I was struck by how different the environment felt in his house to mine. I remember flags and emblems and things, it felt really weird to me, his mum was very well spoken, and it was odd for me. The dad was a very Colonel character, although I was only 6 , I thought this is very different, you start to realize you are different.

Eilish: One thing I noticed where my mum lives, we were the only ones that went out on a Sunday morning by car to mass. Everyone else was washing their cars, we were the only ones that went to mass. So completely different, and they didn't see mass as an issue because it is not to them.

Greta: My friend at primary school had Irish parents, and did Irish dancing, and we went out together and everything was the same. There was another girl at school whose parents were completely English, and it reminds me of how different it was from my house. 
Liam: I still find that even now.

B: What sort of things were different?

Greta: I think it is an atmosphere.

Eilish: You are going to get a picture, a crucifix, a sacred heart, some ornament. Cooking, there is always cooking going on of some sort.

Liam: I was in the same lad's house when I was 13 when the first hunger strike was called off in 1980. I was starting to become aware of things then, and I remember the dad saying, why did they call it off, they should have let them all die. I remember the feeling of complete and utter revulsion. I was so annoyed.

Eilish: Now that we mention food, going to people's houses, if you go to an Irish house, and I didn't notice until I went to an English person's house, it is so different. If I went to your house I would stay to dinner because that is what happens. If you went to a friend's house or relatives you'd get sandwiches, cake and tea. If you stay for half an hour you get biscuits and a cup of tea, if you went to somebody else's house, you'd be waiting for the drink.

Liam: That is a big difference, hospitality, it is just different cultures.

Greta: In Irish houses you get offered a cup of tea.

Liam's intense response to his friend's parents, their environment, and political views is not remarked upon by other group members. His remarks are politicized and form a rupture in this conversation which returns to the 'safety' of the Irish characteristic which is both celebrated and almost a cliché: abundant hospitality. Even a number of years into the peace process in Northern Ireland, the habits of steering clear of political discussion in public spaces can still have effects for Irish people in England (Hickman, 2002). Later in the discussion, the social spaces of the pub or music venue were cited as the places where a gregarious Irish culture was enacted in which Irish people and their families could 'find each other'. This need to search out places where Irishness and a communal sense of belonging could be expressed is discussed in terms of the advantages of being Irish (enjoying the 'craic') as opposed to the deficiencies of 'being English'.

\section{'On being half-Irish and half-English/British'}

A majority of the participants in these discussion groups struggled in one way or another with proportionality when responding to how they would identify themselves. In one of the Coventry groups, a woman tries to express her positioning, acknowledging as she does the extent to which she is within 'the grip' of official discourses and is frustrated by them:

Tricia: I would say I am Irish, but I refer to myself as second-generation Irish, typical social work speak coming out. . . . I couldn't hide from it, I wouldn't ever want to, but both parents and all of my relatives are Irish, I have no other relatives other than Irish ones. I do say that I am born in Coventry, England, and the most important point for me is I 
feel that I have only very recently been able to identify my Irish heritage in a positive way. Because, anything I have ever written down, they have never asked me what my cultural heritage was, I have been white UK, British, white European, nobody has ever asked me until recently, the recent [2001 British] Census. In social work, they are now incorporating Irish as a separate ethnic identity, which is completely new. So I feel really by and large formerly it has gone hidden, and people just guess and ask, people say I look Irish, but would just assume I was English most of the time. Most of my life I have felt between the two cultures, and consequently I can really identify with the English part of my life. As I am maturing, I have really come back and feel much stronger towards my roots, than I did in my 20 s, and early 30s. I have started to realize how strong the Irish is in me, but I do feel between the two cultures and always have done I suppose.

Tricia both critiques the official categories which have not provided space for her Irish heritage to be recorded and expresses a feeling that an ethnic identity which has been hidden is now acknowledged but is still without a category that encapsulates her feeling of being 'between two cultures'. It may well have been her professional background that accounts for her usage of this exact phrasing (the only other participants to do so were all members of the 'caring' professions). A number of other people commented on how their identities changed as they got older and more confident, in most cases they were able to claim Irish identities in a way that had been difficult for them previously. This is a phenomenon that has been noted before (Lennon et al., 1988) and challenges assimilation assumptions.

When asked why she considers herself 'half-English', one woman in Manchester, Eilish, cites birthplace and schooling. A particular understanding of nationality and an implicit cognition of 'being half-English/British' as a recipient of state benefits informed this aspect of her self-characterization. However, when Eilish described growing up with English people she immediately acknowledges they were 'mostly Irish' (that is presumably like herself of Irish descent). This leaves her confused and she does not know what makes her English.

Someone else in the same Manchester discussion commented:

Liam: The second generation haven't got organizations because we subconsciously look for approval, or hang on the coat tails of the first generation. What would be nice out of this is that we have a validity in our own right, we are a separate identity from Irish from Ireland, and British. We are neither one nor the other.

In this discussion group, people struggled for terms in which they can express what is to many the self-evident 'truth' of being, in Liam's words, 'a separate identity from Irish from Ireland, and British'. People struggling with proportionality generally spoke from a position of the relevance of 'British' as a civic identity, although they also used English as a term for 
this. The reference to not having 'any organizations' is an acknowledgement of the public invisibility of second-generation Irish people in Britain. This also indicates the extent to which the research project was perceived as a public raising of issues previously only discussed within the family or in other 'Irish' arenas.

In one of the Banbury discussion groups, the following exchange demonstrated how participants there also held an incipient desire for recognition.

James: It is recognition, though, that is the main thing, I have found this tonight to be really interesting. The only other opportunity I get is if I am talking to cousins, who like me were born here. Then when you sit down and start talking to them about it, they understand, they know what you are talking about. When you say about the duality of am I this, am I that, I am but I am not.

Brian: Needs to be recognized

James: So recognition of this whole community of people is a good thing, and needs to be recognized. You have Boy George, second-generation Irish, Elvis Costello, an awful lot of second generation, Dexy's Midnight Runners (laughs).

These comments reflect struggles to articulate the constitution of 'secondgeneration' subjectivity as perceived and experienced by people of Irish descent. These conversations suggest attempts to establish the 'systems of determinations' or habitus that produces equivalent fields of dispositions and similar possibilities for individual strategies of second-generation Irish people in England (Silverstein, 1996).

\section{On 'being local'}

Identifying with a local area emerged both as a way of avoiding identification with Englishness or Britishness (although the latter was seen as relevant as a legal identity and as representing citizenship), as a way of describing being half-and-half in the absence of a category to describe that, and as a resolution of the problems of invisibility and the need for recognition. A participant in Manchester put it like this:

Liam: I wrote Irish Mancunian [on the Census form]. The reason for that is I identify very strongly with Ireland, I also identify very strongly with Manchester, I don't identify at all with the notion of Britishness or Englishness. I recognize that obviously through experience and birth, it would be a total fallacy to deny the fact that I have experienced British education. I would never just say I am Irish it feels fraudulent to me to say that, like I say I identify strongly with Manchester as well, so I came up with this hybrid.

In Coventry an exchange took place which encapsulated a common dilemma. With no recognition of the specificity of an Irish background, children experience pressures not to stand out or have to explain what all 
these 'big green ribbons' or badges were that they were expected to wear on St Patrick's day by their family.

Tracey: I usually say I am Coventry of Irish parents, so Coventry Irish usually I class myself as. But that has actually changed as I have grown older, I didn't go to a Catholic school, with my mum being disabled she couldn't take me. So I very much hated my name O'Gara when I was young, I really got picked on because of it. Especially at the time when all the bombing was going on, I remember my dad coming home from work saying quite a few things about it. I really hated my name then, but as I got older and became confident and sure about myself, then I really identified with being Irish. I suppose that happened when I was about $15 / 16$, it has changed.

Tom: Did you wish you were English when you were at school?

Tracey: I probably did, I have to say at one point when I was young, yes very much so. I didn't have anyone to identify with. I remember St Patrick's day my nan would send big green ribbons and a badge, my mum would send me off to school in those, and as you can imagine it didn't go down very well. I loved the things my nan sent me, but we didn't know what it was about, but I think at one point I wanted to be rid of it.

Again this passage is indicative of how confidence as an adult leads to greater powers of self-assertion in terms of ethnic identity, both feelings about who they are and how they are prepared to express these identities change over time (see Walter et al., 2002 for further analysis of this finding). Tracey experienced both internal and external pressures, including the impact of IRA bombing campaigns, as a child, attending an interdenominational state school, which she tries to reconcile by 'being English' but as an adult becomes 'Coventry Irish'.

We have outlined different identifications which second-generation Irish people either claim, utilize, or struggle to mould to represent what they feel, especially when asked or challenged to define their ethnic identity. We sought to plot the multiple positions from which second-generation Irish individuals speak and how they are positioning themselves. All of these identifications represent positionings in terms of the national hegemonic domains of England/Britain and Ireland. Whereas one participant describes this as being between two cultures, we would argue that the secondgeneration Irish are at the intersection of two hegemonic domains of rootedness, nation and authenticity with themselves constituted by their parents' migrancy and their own duality located in particular places. Ireland is represented by their upbringing, family life and their imaginings. England/ Britain is represented by education, employment, locality and citizenship. We explore these zones of intersection more closely in the next section. 


\section{HEGEMONIC DOMAINS AND AUTHENTICITIES}

\section{Pressures to 'be English'}

The contesting of their identities by others surfaced in all the discussion groups. Most prevalent was a sense that in England/Britain nothing is done to encourage a sense of Irish identity and that if an individual articulates an Irish identification, they meet resistance, sometimes to the point of argument and estrangement. This was mirrored by the perception that in Ireland claims by people born in England to be 'Irish' are treated more often than not as risible. These two nation states and their 'narratives of differentiation', as well as the drama of their historical relationship, frame the identities and positionings of the second-generation Irish population in England. Ironically, both English hostility when faced with the spectre of Irish identities, and Irish denials of the authenticity of those same identities, utilize the pejorative term 'plastic Paddy' to stereotype and undermine processes 'of becoming' of Irish identities of second-generation Irish people. The message from each is that the second-generation Irish are 'really English' and many of the second generation resist this. Consequently, the pressures of these two hegemonic domains are experienced as part of the materiality of social relations and the relational dynamic of constructing identities as well as in the psychological domain.

In Banbury, Kieran gave an example of the pressure to conform to 'being English' in the work place. He identifies as English and British (see last section) but explains the fall out of someone being identified as secondgeneration Irish at work:

Kieran: .... at work it came up in the last 6 months, ... They probe for one's weak point, they are PE teachers. Delia Cronin is in the office, and she bites all of the time, and I tell her please Delia don't bite. They found out that Delia is second-generation Irish and they go on and on about 'you are English'. I got involved in that in explaining to them, actually I'm in the same situation, oh OK what do you say you are, 'I'm British', so in some ways it made it worse. It has raised an awareness about cultural backgrounds amongst the people there, and now they're talking about Irish, and Scottish and the rest of it. Most people, I suppose are somewhat surprised when I tell them I have an Irish background. It's not something that you say 'oh I'm Irish', but if somebody asks you, or they say I'm going to Ireland this year, we're going to West Cork, and the reason for that, then you explain it.

Delia's 'bite' is something to be controlled. Kieran, sensitive, as someone of an Irish background who identifies as English might be, tries to control her impact himself; in fact sees this aspect of her as symbolizing his distance from Irishness. She is what he is not. However, he gets caught up in the 
fallout from the discovery that she is second-generation Irish. Her colleagues' constant repetition to Delia that she is English is a way of attempting to exert control, regain the secure landscape of homogenous white Englishness.

In Coventry, one man described the context in which he thought the second generation were struggling over their identities in the following way:

Tom: It is a difficult thing, if you have a lot of second-generation Irish, where it is not even something they think about, if you like, a lot.... where I feel it is at, you have an Irish background, all the institutions and there is no positive reinforcement of that in this culture. I imagine it is the same for black people when they are growing up in England, they wish they were white, stuff like that. In a sense it is not an easy thing, how are you going to locate the identity of second generation? That's quite a project. They may be haven't got any strong link with identity, a number of them, they have not really been encouraged by this society. I don't think Britain wants any other ethnic [minority] groups, there is a strong resistance to all of it. If you speak to English people, I get a very 'what do you mean, you are Irish?' Like as if I am stupid or have got a problem. So you don't want to make an issue of it, I find I don't want to make an issue out of it. I think what is the point of getting into arguments and hassle, things like that, so I don't think it is an easy thing to do.

This man identifies what others recount as their experience, that there is no support in the institutional structure in Britain for Irish identities, and under pressure about their identities some choose to maintain a low profile. $\mathrm{He}$ is identifying a project, constituting the subjectivity of secondgeneration Irish people, but thinks this is very difficult because Britain does not want 'any other ethnic groups'. English people think he has a problem or 'is stupid' if he thinks he is Irish. This level of repeated incomprehension from English people was reported across the localities in which we held discussion groups and led in particular instances to varying degrees of estrangement from friends and colleagues.

\section{'Irish' rejections of the second generation}

In Ireland (Republic of Ireland) there has been an historical denial of diaspora, although not of emigration, and a peripheralization of the place of the diaspora in thinking about Irish identities. In recent decades, prior to the 1990s, there was little discussion about the diaspora in the public sphere, although in public discourses reference was (and is) made to 'returned Yanks' or 'plastic Paddies'. The former conveys an ambiguity towards the success story that is deemed to be the Irish-American experience. 'Plastic Paddy' is a term deployed in order to deny and denigrate the second-generation Irish in Britain, the implication being that if 
you were not born in Ireland your claim to Irishness lacks authenticity and can safely be ridiculed. This epithet, 'plastic Paddy', came into quite common use in the 1980s, frequently articulated by new middle-class Irish migrants in Britain, for whom it was a means of distancing themselves from established Irish communities (Hickman 2002).

Two participants in one of the London discussion groups recount how this label or other charges of inauthenticity have impacted on them:

Antoinette: I think when my identity came into being questioned is when I worked at the Irish Centre because that is the first time, when I worked at the Irish Centre, that I have been called a plastic Paddy. . . . I would say, I would definitely say I'm born in Wales, I'm second-generation Irish, you know. I love Irish culture and I love Ireland and I love everything but I wouldn't, I probably wouldn't want to live there. I probably, I would identify myself as second-generation Irish but, you know, I wouldn't completely surround myself within it, if you know what I mean. . . Y You know it's kind of, it's a bit confusing really and it's not only me that's been, I've stood on a platform in Dublin and heard, seen Irish men go back and they're really excited to be in their home country and they have been called plastic Paddies by their own fellow men that have, you know, that are, you know, living in Dublin. And I just think that's all so wrong because, you know, Irish, if you do have Irish parents you are very much entrenched in the culture and you enjoy it and, you know, Irish people do have such a very big sense of community and that's what you love about it so you identify yourself with it but yet it's very confusing identity wise, I've always felt anyway, you know, being second, you know, as if you're not quite there, sometimes I've felt that in the Irish Centre you weren't quite there, you know.

Linda: I always just find that if you haven't got the accent you're not there but you probably can identify, if you're in a pub and you're surrounded by Irish people that accent can come, it's there, and then you catch yourself wondering Jesus what am I, you know.

This naming process, with its message that accent is the primary marker of ethnic identity, ensured that for the second generation their accent and birthplace is held as determinate proof of their Englishness. The desire to be acceptable as Irish can lead an individual to adopt an Irish accent. We found a more negative reaction to the epithet 'plastic Paddy' amongst this cross-section (by gender, age and class) of second-generation Irish than do Mac an Ghaill and Haywood (2003) in their account of the reworking of the term 'plastic Paddy' by young men as part of a process of reclamation and rearticulation of being and belonging. 


\section{DISCUSSION AND CONCLUSION}

This analysis plots the heterogeneity of positionings and voices amongst second-generation Irish people in England and the interrelated ways in which they are positioned by others. It does so in the context of a multiethnic Britain in which 'Englishness' is under pressure not only from the claims of belonging of minority ethnic groups but because of devolution and the integrationist trajectory of the European Union. Whiteness is revealed as limited in power as a guarantor of the discourse of Englishness when disrupted by white people 'born and bred' in England who claim strong allegiances to Ireland; the boundaries of Englishness are not always determined by colour but are also predicated on notions of cultural belonging which do not allow any hybridized identifications. Future analyses will seek to delineate the gender, class, regional and other differences inscribed in these identifications and positionings. We also intend to produce future papers which analyse the different context of Scotland for the identifications and positionings of people of Irish descent in Britain; and compare these with the different contextualization of Irish-American identifications in the USA.

The points of identification articulated by these second-generation Irish people were principally framed by the discourses of two hegemonic domains: England and Ireland. One domain (England) is incorporating, denying the difference of 'Irishness'; the other domain (Ireland) is differentiating, denying of commonalities with people of Irish descent. There was substantial and consistent evidence that the second-generation Irish are positioned as having to defend charges of inauthenticity both from those pressuring them to be English and from those denying their Irish identifications. Ireland rejects these 'hybrids' as not Irish, as in fact English, and England cannot countenance any dilution of whiteness or weakening of the hegemonic subject and thus also insists on their Englishness. The hegemonies we are discussing are those which surface when people identify themselves, perceive others, experience the world, interpret their predicaments and orient their actions in racial, ethnic or national terms.

Ahmed et al. (2000) note that there is little literature on second generations in Britain and that the tendency has been to construct them pathologically as 'caught between two cultures'. Instead of conceptualizing this positionality as being 'between two cultures' what we argue is that one of the arenas in which these hegemonic domains intersect is in the lives of children of Irish-born parents living in England with material and psychological consequences for this second generation. Describing this positionality as 'caught between two cultures' implies being locked in position between an inability to achieve full assimilation in England and an inability to achieve full membership in Ireland. The participants in these 
discussions were more concerned with expressing and gaining recognition for the complexity of the identifications and positionings of the second generation. The desire of the majority was for recognition of this hybridity rather than for the key to a successful trajectory along either assimilatory path. Many participants expressed or wished there was a way of articulating allegiances to more than one domain, conjoined as their 'second generationness' and contingent upon their locational specificity. These simultaneous, compatible loyalties made sense if you were secondgeneration Irish in England, but did serve to differentiate and position the individuals in the eyes of others.

In these discussion groups, the participants switched often between the terms English and British (or England and Britain). Sometimes they reproduced the conflation of the terms common in the past and still evident in England, more often they were precisely aware of which term they were using. The division in the 2001 British Census question of the White category into British/Irish/Other was perceived both as a question about nationality and as mirroring the challenge many experienced in everyday encounters - 'Are you English or Irish?' - even though the terms are different. We found no evidence of second-generation Irish people being challenged to proclaim their Britishness, constituting recognition of the conglomerative role of 'British' as a category, both historically and at the present time. In England, however, where a massive numerical majority of all immigrant and second/third generation populations reside, the strength of the association of Englishness and whiteness is disrupted and threatened by second-generation Irish assertions of Irish allegiances. In this context, 'British' is affirmed as an acceptable element in many individuals' articulations of hybridity; others, however, rejected it in favour of a local identity to 'pestle together' with Irishness.

The second-generation Irish material we have presented here reveals the instability of any 'hard and fast' drawing of a colour line to explain patterns of acceptance and belonging in multiethnic Britain. The daily ruptures of it by white people born and brought up in England who assert a claim to differentiation, to possibly being British (more rarely English) by birth and nationality, but to having Irish identities and heritage or to 'being Irish', are resisted strongly by English friends or work mates/colleagues. Their allegiances to Ireland are not acceptable and disturb the universe of white Englishness. These ruptures reveal the limitations of whiteness and the boundaries of Englishness and de-authorize the hegemony of Englishness from within the circle of whiteness. 'Visible' minority ethnic groups must stake a claim for full acceptance as British in a context where their 'difference' is designated/recognized 'on sight'; they are involved in a constant process of asserting their belongingness in a context which does not assume it. No attempt is made by most to assert Englishness because of the association of whiteness with the 'discourse of Englishness' and its 
racialized understandings of place and belonging (see Rattansi, 2000; Younge, 2000). Those who wish to express the Irish dimension of their identity(ies) have to stake a claim to differentiation because Englishness does not include an acceptance of internal difference at the level of cultural belongingness. And it is at the point of asserting this difference, of highlighting diversity within whiteness, that negative and estranging responses are generated in ethnonational terms. Racialized differentiations underpin the encounters within which the second-generation Irish are relationally constituted and the price for 'being English' goes beyond the invalidation of other ethnic/national ties. In this context, strategies of incorporation directed at the Irish in England since the Second World War are about binding them to whiteness as a set of social practices with specific inclusions and exclusions (see Hickman, 1995, 1998a; Walter 2001). The constant denial of the difference of people with white skins and 'English' accents who assert Irish identifications reveals the weakness and vulnerability of Englishness and reproduces the positioning of intimate betrayer accorded the Irish within historical memory of British-Irish relations.

\section{Acknowledgements}

We would like to thank Gail Lewis, Patrick Wolfe, Lemah Bonick, Celia Jenkins and three anonymous reviewers of Ethnicities for their comments, although responsibility for the contents remains entirely with us.

\section{Notes}

1 An ESRC-funded research project 'The Second-Generation Irish: A Hidden Population in Multi-Ethnic Britain' (reference number: R00023836); see [www. apu.ac.uk/geography/progress/Irish2].

\section{References}

Ahmed, B., P. Nicolson and C. Spenser (2000) 'The Social Construction of Racism: The Case of Second Generation Bangladeshis', Journal of Community and Applied Social Psychology 10: 33-48.

Anthias, Floya \& Yuval-Davis, Nira (1992) Racialized Boundaries: Race, Nation, Gender, Colour and Class and the Anti-racist Struggle. London: Routledge.

Arrowsmith, A. (2000) 'Plastic Paddy: Negotiating Identity in Second Generation "Irish-English" Writing', Irish Studies Review 8(1): 35-43.

Bonnett, A. (2000) White Identities, Historical and International Perspectives. Harlow: Prentice Hall.

Brah, A. (1996) Cartographies of Diaspora. London: Routledge

Brubaker, R. (2001) 'Cognitive Perspectives', Symposium on Ethnicity, Ethnicities 1(1): $15-17$.

Campbell, S. (1998) 'Race of Angels: The Critical Reception of Second-generation Irish Musicians', Irish Studies Review 6(2): 165-74. 
Campbell, S. (1999) 'Beyond "Plastic Paddy": A Re-Examination of the Secondgeneration Irish in England', Immigrants and Minorities 18(2 \& 3): 266-88.

Campbell, S. (2000) 'Britpop: The Importance of being Irish - The Relevance of Ethnicity for Understanding Second Generation Irish Musicians in England', in T. Mitchell and P. Doyle (eds) Changing Sounds: New Directions and Configurations in Popular Music. Sydney: University of Technology.

Campbell, S. (2002) 'Sounding Out the Margins: Ethnicity and Popular Music in British Cultural Studies', in G. Smyth and G. Norquay (eds) Across the Margins: Cultural Identities and Change in the Atlantic Archipelago. Manchester: Manchester University Press.

Cohen, P. (1988) 'The Perversions of Inheritance: Studies in the Making of Multiracist Britain', in P. Cohen and H. Bains (eds) Multi-racist Britain. London: Macmillan.

Cohen, P. (1999) 'Through a Glass Darkly: Intellectuals on Race', in P. Cohen (ed.) New Ethnicities, Old Racisms, London: Zed Books.

Free, M. (1998) “"Angels” with Drunken Faces? Travelling Republic of Ireland Supporters and the Construction of Irish Migrant Identity in England', in A. Brown (ed.) Fanatics! Power, Identity and Fandom in Football. London: Routledge.

Goulbourne, H. (1998) Race Relations in Britain since 1945. Basingstoke: Macmillan.

Harding, S. and R. Balarajan (1996) 'Patterns of Mortality in Second Generation Irish living in England and Wales: Longitudinal Study', British Medical Journal 312: 1389-92

Harte, L. (2003) " "Somewhere beyond England and Ireland": Narratives of "Home" in Second-generation Irish Autobiography', Irish Studies Review 11(3): 293-305.

Hickman, M.J. (1990) 'A Study of Incorporation of the Irish in Britain with Special reference to Catholic State Education: Involving a Comparison of the Attitudes of Pupils and Teachers in Selected Secondary Schools in London and Liverpool', Ph.D. thesis, University of London Institute of Education, London.

Hickman, M.J. (1995) Religion, Class and Identity. Aldershot: Avebury.

Hickman, M.J. (1998a) 'Reconstructing Deconstructing "Race": British Political Discourses about the Irish in Britain', Ethnic and Racial Studies 21(2): 288-307.

Hickman, M.J. (1998b) 'Secularisation amongst Irish Catholic Emigrants and their Descendants in Britain', in P.Brennan (ed.) La Sécularisation en Irelande. Caen: Presses Universitaires de Caen.

Hickman, M.J. (1999) 'The Religio-Ethnic Identities of Teenagers of Irish Descent', in M. Hornsby-Smith (ed.) Catholics in England 1950-2000. London: Cassell.

Hickman, M.J. (2002) “ "Locating” the Irish Diaspora', Irish Journal of Sociology 11(1): 8-26.

Hickman, M.J. (forthcoming) 'Ruling Empire, Governing the Multi-National State: the impact of Britain's historical legacy on the contemporary ethno-racial regime', in G. Loury, T. Modood and S. Teles (eds) Ethnicity and Public Policy in the US and UK. Cambridge: Cambridge University Press.

Hickman, M.J and B. Walter (1997) Discrimination and the Irish Community in Britain. London: Commission for Racial Equality.

Hickman, M.J, S. Morgan and B. Walter (2001) Second-Generation Irish People in 
Britain: A Demographic, Socio-Economic and Health Profile. London: Irish Studies Centre, University of North London.

Lennon, M., M. McAdam and O'Brien, J. (1988) Across the Water: Irish Women's Lives in Britain. London: Virago.

Lewis, G. (1998) Forming Nation, Forming Welfare, London: Routledge with the Open University Press.

Mac an Ghaill, M. and C. Haywood (2003) 'Young (Male) Irelanders: Postcolonial Ethnicities - Expanding the Nation and Irishness', European Journal of Cultural Studies 6(3): 386-403.

Modood, T. (1996) 'The Changing Context of 'Race' in Britain: A Symposium', Patterns of Prejudice 30(1): 3-13 and 36-42.

Modood, T., R. Berthoud and J. Nazroo (2002) “"Race”, Racism and Ethnicity: A Response to Ken Smith', Sociology 36(2): 419-26.

Parekh, B. (2000) Report of the Commission on the Future of Multi-Ethnic Britain. London: Runnymede Trust.

Rattansi, A. (2000) 'On Being And Not Being Brown/Black-British: Racism, Class, Sexuality and Ethnicity in Post-imperial Britain', interventions 2(1): 118-34.

Silverstein, P. (1996) 'Realizing Myth. Berbers in France and Algeria', Middle East Report July-September: 11-15.

Ullah, P. (1985) 'Second Generation Irish Youth: Identity and Ethnicity', New Community 12(2): 310-20.

Ullah, P. (1990) 'Rhetoric and Ideology in Social Identification: The Case of Second Generation Irish Youth', Discourse and Society 1(2): 167-85.

Walter, B. (1998) 'Challenging the Black/White Binary: The Need for an Irish Category in the 2001 Census', Patterns of Prejudice 32(2): 73-86.

Walter, B. (2000) " "Shamrocks Growing out of their Mouths": Language and the Racialisation of the Irish in Britain', in Kershen, A. (ed.) Language, Labour and Migration. Abingdon: Ashgate.

Walter, B. (2001) Outsiders Inside. Whiteness, Place and Irish Women. London: Routledge.

Walter, B., S. Morgan, M.J Hickman and J. Bradley (2002) 'Family Stories, Public Silence: Irish Identity Construction among the Second Generation in England', Scottish Geographical Journal 118(3): 201-17.

Young, I.M. (1990) Justice and the Politics of Difference, Princeton, NJ: Princeton University Press.

Younge, G. (2000) 'On Race and Englishness', in S. Chen and T. Wright (eds) The English Question. London: Fabian Society.

Yuval-Davis, N. (2001) 'Contemporary Agenda for the Study of Ethnicity', Symposium on Ethnicity, Ethnicities 1(1): 11-13.

MARY J. HICKMAN is Professor of Irish Studies and Sociology and Director, Institute for the Study of European Transformation, London Metropolitan University. Address: Institute for the Study of European Transformation, London Metropolitan University, 166-200 Holloway Road, London N7 8DB, UK. [email: mary.hickman@londonmet.ac.uk] 
SARAH MORGAN is a former Research Fellow on the Irish 2 project and is now Senior Research Officer, Local and Regional Government Research Unit, Office of the Deputy Prime Minister. [email: dympna101@hotmail.com]

BRONWEN WALTER is Professor of Irish Diaspora Studies in the Department of Geography, Anglia Polytechnic University. Address: Department of Geography, Anglia Polytechnic University, East Road, Cambridge CB1 1PT, UK. [email: b.walter@anglia.ac.uk]

JOSEPH BRADLEY is a Senior Lecturer in Sports Studies in the Department of Sports Studies, University of Stirling. Address: Department of Sports Studies, University of Stirling, Stirling FK9 4LA,UK. [email: j.m.bradley@stir.ac.uk] 